\author{
THE WORLD BANK \\ Policy Planning and Research Staff
}

Infrastructure and Urban Development Department

\title{
Housing and Labor Market Distortions in Poland: Linkages and Policy Implications
}

By Stephen K. Mayo

James I. Stein

June 1988

Discussion Paper

This is a document published informally by the World Bank. The views and interpretations herein are those of the author and should not be attributed to the World Bank, to its affiliated organizations, or to any individual acting on their behalf. 
Copyright 1988

The World Bank

1818 H Street, N.W.

All Rights Reserved

First Printing June 1988

This is a document published informally by the World Bank. In order that the information contained in it can be presented with the least possible delay, the typescript has not been prepared in accordance with the procedures appropriate to formal printed texts, and the World Bank accepts no responsibility for errors.

The World Bank does not accept responsibility for the views expressed herein, which are those of the author and should not be attributed to the World Bank or to its affilia . I organizations. The fir,dings, interpretations, and conclusions are the results of research supported by the Bank; they do not necessarily represent official pulicy of the Bank. The designations employed, the presentation of material, and any maps used in this document are solely for the convenience of the reader and do not imply the expression of any opinion whatsoever on the part of the World Bank or its affiliates concerning the legal status of any country, territory, city, area, or of its authorities, or concerning the delimitations of its boundaries or national affiliation.

The authors are indebted to Per Ljung for support and encouragement in undertaking this research, and for helpful suggestions through several drafts. Helpful comments were also provided by Bob Buckley, Bill Fox and Stove Malpezzi. The authors are solely responsible, however, for the content of the paper. 


\section{Housing and Labor Market Distortions in Poland: Linkages and Policy Implications}


EOUSING AID LABOR MARKET DISTORTIOUS IN POLAND:

LIRKAGES AIJ POLICY IMPLICATIONS

Table of Contents

Page No.

ABS-IACT

- iv -

I. INTRODUCTION $\ldots \ldots \ldots \ldots \ldots \ldots \ldots \ldots \ldots \ldots \ldots \ldots \ldots \ldots \ldots \ldots \ldots \ldots \ldots$

II. HOUSING MARKET DISTORTIONS AFFECT LABOR MARKETS $\ldots \ldots \ldots \ldots \ldots$.

III. $\quad$ BACKGROUND $\ldots \ldots \ldots \ldots \ldots \ldots \ldots \ldots \ldots \ldots \ldots \ldots \ldots \ldots \ldots \ldots \ldots \ldots \ldots$

IV. A MODEL OF HOUSING-INDUCED LABOR MARKET DISTORTIONS $\ldots \ldots \ldots$

A. Is There Housing Market Disequilibrium? .............. 7

Do Prices Exceed Costs? ........................ 7

Is Investment Less than Investment in similar

Countries? ................................ 8

B. Is There Labor Market Disequilibrium? ................. 11

Is The Flow of Labor Affected? .................. 11

Are Wage Rates Distorted? ...................... 13

v. EMPIRICAL MODELS $\ldots \ldots \ldots \ldots \ldots \ldots \ldots \ldots \ldots \ldots \ldots \ldots \ldots \ldots \ldots \ldots \ldots$

A. Housing Investment and the Housing Shortage ........ 16

B. Net Migration and Housing Market

Disequilibrium .......................... 17

c. The Wage Rate and Housing Market

Disequilibrium ............................ 19

vi CONCLUSIONS AND POLICY IMPLICATIONS $\ldots \ldots \ldots \ldots \ldots \ldots \ldots \ldots \ldots \ldots \ldots$

A. Increase Resource Allocation to the

Housing Sector ........................... 24

B. Expand the Role of the Private Housing Sector ....... 25

C. Restruccure and Reduce Housing Subsidies ........... 26

D. Increase the Supply of Building Materials .......... 27 
Page No.

ANNEX

TABLES

Table 1: Housing Shortages in Selected E.C.E. Countries Countries (Ratios of Households to Dwelling

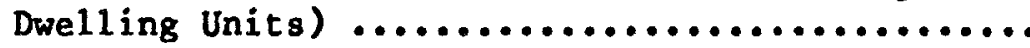

Table 2: Recent Trends in Housing Sector Output ............

Table 3: Housing Investment Relative to GDP in Selected Countries (Percent)

Table 4: Standard Deviation Relative to Average Earnings in the Main and Industrial Sectors in Selected East European Countries, 1976

Table 5: Average Month1y Wages in Poland, $1985 \ldots \ldots \ldots$

Table 6: Results of Housing Investment Regression ..........

Table 7: Results from Net Migration Regressions ...........

Table 8: Results from Earnings Regressions ...............

FIGURE Share of Housing Investment to Gross Domestic 


\section{ABSTRACT}

Poland's housing and macroeconomic policies have restricted investments in housing and urban infrastructure to a level well below that of other European countries. This has resulted in a shortage of housing typified by 15 to 20 year waits for government-subsidized housing and a stock of housing that falls short of the number of Polish households by about 20 percent. Shortages of this magnitude are likely to cause distortions that extend far beyond the housing sector, with impacts on patterns of savings and consumption, the price level, and on the functioning of labor inarkets--all of which have potentially major macroeconomic implications.

This paper focuses particularly on how housing market distortions are transmitted to labor markets, with impacts on rates of migration, relative wage levels among different regions, and, by implication, on the productivity of the Polish work force. The basic thesis of the paper is that if housing markets are prevented from reaching their competitive equilibrium that labor markets will similarly be prevented. The paper examines evidence $c n$ the extent of housing and labor market disequilibria, and estimates econometric models that relate internal migration and relative wages to alternative measures of housing market disequilibria. From these analyses it is concluded that labor markets are in fact distorted by housing market distortions, with potentially major macroeconomic costs.

The paper concludes with a number of recommendations for policy reform.

While the empirical results have direct relevance to Poland, it is likely that the thesis of the paper has relevance not only in other centrally planned economies, but in other economies where government housing market interventions such as rent control or restrictive land use and building regulations preven: housing markets from reaching a competitive equilibrium. 
HOUSING AND LABOR MARKBT DISTORTIONS IN POLAND:

LIMKAGES AID POLICY INPLICATIONS

\section{INTRODUCTION}

The housing situation in Poland has long been one of imbalance, with persistent housing shortages despite large subsidies to the housing sector. These imbalances have many costs to the economy. Increased investments in housing could lead to higher GNP growth than do alternative investments; incremental rates of return on housing investment may be as high as 15 to more than 30 percent, extremely high by international standards. Another way to look at the direct benefit to the economy from housing investment is to calculate the value of construction required to eliminate housing deficits; at a minimum these benefits are about 40 percent of Poland's gross domestic product. If Moreover restrictions on private housing production and poorly structured subsidies dampen household incentives to save for housing purchases, and thus they may reduce the supply of domestic savings to the rest of the economy. Furthermore, housing subsidies, particularly off-budget housing finance subsidies, contribute to inflation.

Tt may also be the case that housing market distortions result in labor market distortions with further penalties in economic performance. Our thesis is that in an economy in which housing markets are prevented from reaching competitive equilibrium, labor markets may also be kept from their competitive equilibrium. This paper examines this prospect and then, based on our analysis of the resulting macroeconomic costs, suggests some implications for hcusing policy reform.

While the arguments advanced concerning induced labor market distortions resulting from housing market distortions are shown to have particular relevance in Poland, the basic arguments are likely to apply more broadly. This is particularly true in centrally planned economies, which have systematically restricted housing and related infrastructure investments. Moreover, it is possible to argue by analogy that other sorts of government housing market interventions such as rent control or particularly restrictive land use and building codes can have similar distorting effects on labor markets, raising wages and decreasing productivity.

\footnotetext{
$1 /$ See Mayo (1987) for an explanation of these estimates.
} 


\section{HON HOUSING MARKET DISTORTIONS APEECT LABOR MARKBTS}

Our model is a simple one. In market economies labor seeks its highest return by moving to areas with higher wages. This process allows more proalrtive firms, industries, and areas to outbid their less productive coun.erparts. The assumption is that households will be able to find housing that will accommodate their move, at a price that permits their real incomes to increase. If the price of housing is too high for mobility to occur, two kinds of adjustments may occur: (1) either more housing will be built, reducing real housing costs, or (2) wages will adjust upward further to compensate workers for high housing costs. In market economies, the empirical evidence is thit the elasticity of housing supply is high enough such that housing shortages would be expected to be el-ainated relatively quickly as a result of increased supply. In non-market (centrally-planned) economies there is no necessary presumption that this would occur. If insufficient resources are devoted to housing, housing disequilibrium could be extreme, with high excess demand and prices well above costs, and $1 \mathrm{ittle}$ housing adjustment. Instead, wages would have to adjust in order to provide a compensatory differential to workers for housing to bear higher housing costs. These costs could include higher housing prices, longer work commutes, and poorer hopging conditions such as low housing quality and doubled-up households. 2 /

To preview what follows, after describing Poland's housing situation, we argue first that Poland's housing market is in disequilibrium by showing that housing prices greatly exceed costs, that the country's rate of investment in housing is low compared to other countries at similar levels of development, and that housing investment has not responded to disequilibrium. Second, using a simple model of net migration, we argue that the housing market disequilibrium depresses labor mobility. Third, using an earnings regression model, we show that housing market disequilibrium affects wage rates. We conclude the paper with a discussion of suggested near and medium term housing policy reforms compatible with Poland's economic situation.

2/ Societies incur costs from these disequilibrium wage differentials. Firms pay wages higher than competitive wages. On the other hand, although households receive higher wages, they are forced to consume a suboptimal bundle of goods and services. Wage differentials are not therefore indicative of real differentials in welfare. Detailed calculation of these welfare losses is beyond the scope of this paper. 


\section{BACKGROURD}

The two dominant features of housing in Poland are shortage and subsidies. Housing output in Poland has in relative terms been lower than that of almost all countries with similar incomes. The result is that among the twenty-eight largest Economic Commission for Europe (ECE) countries in 1980, Poland ranked last in terms of the number of housing units relative to households, with about eighteen percent more households than housing units. On-budget housing subsidies represent a major portion of government expenditures (thirteen percent in 1985), ranking behind only food among consumer subsidies. When account is taken of off-budget interest subsidies, the housing sector may rank as the most prominent area of consumer subsidies.

The most striking feature of the Polish housing sector, however, is the shortage of housing units relative to households. In 1984, there were 12.08 million households in Poland but only 10.25 m.1lion occupied dwelling units, a shortfall of 1.83 million dwellings. Of this latter number, most ( 1.27 million) were in urban areas. Such shortfalls find expression in waiting 1 ists for state and cooperative housing where, in 1986, there were roughly 3 million households signed up--not only dnubled-up households but also households wishing to improve housing quality, space, or location. Average waiting times for cooperative housing in large cities (Warsaw, Katowice, etc.) are reported to be from fourteen to fifteen years, and in the citias with the shortest waiting times (small cities in eouthern Poland), households could expect to wait five to six years for a cooperative apartment.

The housing deficits that exist now can be best understood in historical and comparative perspective. As a result of the destruction of World War II, Poland emerged with one of the most severe housing deficits in Europe-households exceeded housing units by about 1.5 million units at a time when the stock comprised about 5.5 million units. In the early years after the war, reconstruction proceeded slowly. By 1960, Poland still had one of the highest relative shortages of housing in Europe with 25 percent more households than housing units-a deficit of about 1.2 million units. In relative terms, only the U.S.S.R. (with a 29 percent deficit), the Federal Republic of Germany ( 28 percent deficit), and the German Democratic Republic (25 percent deficit) were close to the levels of relative shortage exhibited by Poland in 1960 .

Housing shortage ratios (measured in terms of households relative to dwellings) in these four countries with the most serious war-related deficits, which are compared tc those of other ECE countries in Table 1, were well above the median ratios for all countries in 1960--1.03 for western countries and 1.16 for socialist countries. After 1960, housing production increases decreased housing deficits in both western and socialist countries. By 1970, parity between households and dwellings had been achieved in Western Europe and North 
Table 1: HOUSING SHORTAGES IN SELRCTED B.C.B. COUNTRIBS

(Ratios of Households to Dwelling Units)

\begin{tabular}{|c|c|c|c|}
\hline Country & 1960 & $\begin{array}{l}\text { Year } \\
1970 \\
\end{array}$ & 1980 \\
\hline \multicolumn{4}{|c|}{ North America and Western Europe: } \\
\hline $\begin{array}{l}\text { Austria } \\
\text { Belgium } \\
\text { Canada } \\
\text { Denmark } \\
\text { Fed. Republic of Germany } \\
\text { Finland } \\
\text { France } \\
\text { Greece } \\
\text { Iceland } \\
\text { Ireland } \\
\text { Italy } \\
\text { Luxembourg } \\
\text { Netherlands } \\
\text { Norway } \\
\text { Portugal } \\
\text { Spain } \\
\text { Sweden } \\
\text { Switzerland } \\
\text { United Kingdom } \\
\text { United States }\end{array}$ & $\begin{array}{l}1.04 \\
0.97 \\
0.99 \\
1.08 \\
1.28 \\
1.11 \\
0.93 \\
0.97 \\
1.12 \\
1.09 \\
1.00 \\
1.03 \\
1.09 \\
0.92 \\
0.99 \\
1.00 \\
1.00 \\
1.04 \\
1.02 \\
0.93\end{array}$ & $\begin{array}{l}0.96 \\
0.97 \\
0.99 \\
1.00 \\
1.09 \\
1.02 \\
0.85 \\
0.86 \\
1.09 \\
1.08 \\
0.95 \\
0.98 \\
1.01 \\
0.85 \\
0.84 \\
0.98 \\
0.98 \\
0.98 \\
1.00 \\
0.95\end{array}$ & $\begin{array}{l}0.92 \\
0.94 \\
0.99 \\
0.99 \\
1.01 \\
1.00 \\
0.87 \\
0.79 \\
0.95 \\
1.04 \\
1.01 \\
0.93 \\
0.99 \\
0.84 \\
0.73 \\
0.99 \\
0.90 \\
0.90 \\
0.96 \\
0.95\end{array}$ \\
\hline Median & 1.03 & 0.98 & 0.95 \\
\hline \multicolumn{4}{|l|}{ Eastern Europe: } \\
\hline $\begin{array}{l}\text { Bulgaria } \\
\text { Czechoslovakia } \\
\text { German Democratic Republic } \\
\text { Hungary } \\
\text { Poland } \\
\text { Romania } \\
\text { U.S.S.R } \\
\text { Yugoslayia }\end{array}$ & $\begin{array}{l}1.10 \\
1.16 \\
1.25 \\
1.16 \\
1.25 \\
1.16 \\
1.29 \\
1.14\end{array}$ & $\begin{array}{l}1.14 \\
1.08 \\
1.09 \\
1.10 \\
1.16 \\
1.15 \\
1.09 \\
1.07\end{array}$ & $\begin{array}{l}1.08 \\
1.01 \\
1.02 \\
1.08 \\
1.18 \\
1.12 \\
1.05 \\
1.02\end{array}$ \\
\hline Median & 1.16 & 1.10 & 1.07 \\
\hline
\end{tabular}

Source: Calculated from Tables I.6 and iII.1, United Nations Economic Commission for Europe (E.C.E), (1986). 
America (the median ratio of households to dwellings was 0.98 ), and deficits had been reduced in socialist countries, to a median ratio of 1.10. The reduction in housing deficits was particularly striking between 1960 and 1970 for the three countries other than Poland that had suffered the most serious war-related shortages. Poland had however fallen to last place among the countries of Table 1 in 1970, with 16 percent more households than dwellings. From 1970 to 1980 , housing deficits continued to fall in both Western Europe and the socialist countries, with the median ratio of households to dwellings reaching 0.95 in the West and 1.07 in socialist countries. By 1980, virtual parity between households and dwellings had been achieved by several socialist countries--Czechoslovakia, the German Democratic Republic, and Yugoslavia. In Poland, by contrast, the housing de it was as high in percentage terms in 1980 as it was in 1970 , with $\&$. 18 percent more households than dwellings.

These housing deficits have proven to be intransigent to considerable efforts by the Poles to reduce them since the early 970s. In 1972, for example, the Sejm (the Polish parliament) announced - conprehensive program to expand housing production from an annual level of output of 6.5 dwellings per 1000 people in 1971-1975 to 9 per 1000 peopl.? in 1976-1980 and to 11 or more per 1000 people in 1981-1990.

Table 2 indicates actual output, in terms of both dwellings per 1000 people and numbers of dwellings completed annually. During the $1970 \mathrm{~s}$, poduction goals were met, with output equal to 6.7 dwellings per 1000 people. In the late 1970 s, production was climbing toward the goal of nine dwellings per 1000 people, and attained a peak of 8.1 dwellings por 1000 people during 1978, when numerical output also peaked at 284,000 dwelling units. In the next three years, and mirroring general economic conditions in Poland, output fell by about one-third to a level that had been typical of the $1960 \mathrm{~s}$. Output has barely recovered from a nadir of 186,000 dwelling units in 1982 ( 5.1 per 1000 population).

There are three major spyrces of housing in Poland: state, cooperative, and private housing. 3 Over time the relative importance of supply from each of these sources has varied as a reflection of the state's role in the housing supply system. Before World War II, most housing was supplied privately. After the war, the state began to

3/ A fourth s.jurce of housing--built by industrial establishments for their employees--was an important source of supply during the $1940 \mathrm{~s}$ and 1950s. It is still used where housing shortages are critical. We have no separate statistics to identify this source of housing, but it could be as much as 12 percent of the 1978 total housing stock if it is the same as the category "other socialized housing" in Poland's statistical yearbook. Ciechocinska (1987) reported that, as of $1978,7.7$ percent of Warsaw's apartments were owned by enterprises. 
produce and finance an increasing share of new housing. Beginning in the late 1950s, the state's role shifted towards sponsorship of cooperative housing rather than state housing, and by 1965 cooperative housing had become the major source of new supply. The existing stock If housing continues to reflect the pre-war legacy of private housing; in 1978, private housing made up 49.6 percent of the housing stock, with the remainder roughly equally divided between state and cooperative housing .

Table 2: RECENT TRENDS IN HOUSING SRCTOR OUTPUT

\begin{tabular}{lcc}
\hline Year & $\begin{array}{l}\text { Dwellings Completed } \\
\text { per 1000 Population }\end{array}$ & Number \\
\hline & & \\
1970 & 6.0 & 194,000 \\
1971 & 5.8 & 191,000 \\
1972 & 6.2 & 206,000 \\
1973 & 6.8 & 227,000 \\
1974 & 7.4 & 250,000 \\
1975 & 7.3 & 248,000 \\
1976 & 7.7 & 264,000 \\
1977 & 7.7 & 266,000 \\
1978 & 8.1 & 284,000 \\
1979 & 7.9 & 278,000 \\
1980 & 6.1 & 217,000 \\
1981 & 5.2 & 187,000 \\
1982 & 5.1 & 186,000 \\
1983 & 5.4 & 196,000 \\
1984 & 5.3 & 196,000 \\
1985 & 5.2 & 193,000 \\
& & \\
\hline
\end{tabular}

Elsewhere (see Mayo, 1987) we have discussed both the factors inhibiting housing output in Poland, and some of the macroeconomic implications of housing shortages. Among the most apparent are potentially reduced economic growth, as a result of foregoing high return investments in housing and infrastructure; reduced incentives to save and invest by households, because of housing subsidies and government restrictions on housing and infrastructure investment; and increased inflationary pressures, because of large off-budget subsidies for housing and persistent excess housing demand. These macroeconomic impacts are all potentially large and constitute sufficient justification for major housing policy changes. They fail, however, to capture the full extent of macroeconomic distortion created by inappropriate housing policy. In particular, it seems likely that housing market distortions are propagated through labor markets, by distorting patterns of internal migration, commuting, job search, and wage structures. Were it possible to establish the existence and magnitude of such labor market distortions, it would increase the stakes of undertaking housing policy reform. In the following three sections we explore the nature and extent of labor markst distortions as they are indu_ed by housing market distortions. 


\section{A MODEL OP HOUSING--INDUCED LABOR MARKET DISTORTIONS}

The model we use to identify the linkages between the housing and labor markets in poland contains three components: (1) housing market disequilibrium, (2) migration flow disequilibrium, and (3) labor market disequilibrium. In this section we will examine the evidence on distortions in each of these markets.

\section{A. Is There Housing Market Disequilibrium?}

We argue that the housing market is shown to be in disaquilibrium if (1) housing prices exceed costs, (2) housing investment is too low, and (3) housing investment does not respond to the housing shorcage. The first two aspects of disequilibrium are taken up here; the ihird aspect is discussed with the other statistical analyses in section $V$.

\section{Do Prices Exceed Costs?}

There is a vast discrepancy between what housing appears 10 be worth and what most people pay for it. The deficits in housing have produced a situation in which housing that becomes available on the free market often sells for prices well in excess of construction costs; at the same time, however, and in part because of the housing subsidy system, households living in the existing housing stock are spending unusualiy low fractions of income for housing relative to what households in similar non-socialist countries spend, and relative to the cost of new free-market housing within Poland.

Information on free-market housing prices is largely anecdotal, but available information indicates that prices of housing units that trade on the free market (potentially up to about 60 percent of the stock) are well in excess of costs of construction or replacement. For example, discussions in 1986 with officials of heusing cooperatives and their national association indicated that relatively large units (80-100 square meters) in older coops (built in the late 1950 s) in Warsaw had recently sold for prices of from 120,000-150,000 zlotys per square meter. Selling prices for newer units were said to depend on unit size, with smaller units selling for about 60,000 zlotys per square meter and larger units, which are relatively more scarce, selling for about 120,000 zlotys per square meter. 4 Independent

4/ Ciechocinska (1987) indicated that the price of flats in Warsaw avereged 100,000 zlotys per square meter in 1985, and that a "typical flat" for a family of three could be assumed to be about 5 million zlotjs. 
conversations with private citizens in Warsaw confirmed that such prices are typical for free market sales and are also consistent with black market prices of rental housing.

Prices at these levels appear to be well above construction costs. Nationwide, cooperative construction custs averaged about 24,000 zlotys per square meter in 1983-1984. Since that time, construction cost indices have risen by about 59 percent, so current costs are estimated to be about 40,000 zlotys per square meter. In Warsaw and other large cities, costs are reported to be higher, perhaps in a range of 50,000 to 75,000 zlotys per square meter. Thus it appears that the market price of housing can exceed construction costs to a considerable degree. 57

Is Investment Less than Investment in Similar Countries?

Poland's level of investment in housing has been lower than that of other countries with either similar levels of GNP per capita or similar levels of housing deficits. Table 3 illustrates housing

Table 3: HOUSIMG INVESTMENT RELATIVE TO GDP IN SELECTED COUNTRIES

(Percent)

\begin{tabular}{llll}
\hline Country & 1970 & \multicolumn{1}{c}{ Year } \\
1975 & 1980 \\
\hline Czechoslovakia & 4.95 & 5.27 & 4.01 \\
Hungary & 4.11 & 5.99 & 5.59 \\
Poland & 3.89 & 4.34 & 5.52 \\
Romania & n.a. & 4.67 & 4.59 \\
Yugoslavia & 5.76 & 6.77 & 7.76 \\
Greece & 6.60 & 5.36 & 5.76 \\
& & & \\
\hline
\end{tabular}

Source: Residential construction statistics were taken from the United Nation's National Accounts Yearbook. Construction variables for socialist nations are the sum of gross investment in owner-occupied and non-communal housing. Gross domestic product estimates for socialist nations were taken from World Bank Staff Working Papers. The sources are: (a) Zbigniew Fallenbuchl, 1985; (b) Peter Havlik and Friedrich Levcik, 1985; (c) Edward Hewett, 1985; and (d) Marvin Jackson, 1985.

5/ Such differentials between cost and price are indicative of high real rates of return to housing investment (perhaps 15 to more than 30 percent) and suggest the welfare losses associated with not allowing sufficient resources to be invested in the housing sectcr. 
investment relative to GDP for five socialist countries and for Greece (which has relatively similar GDP per capita) for 1970, 1975, and 1980. As the table indicates, Poland's comparative investment performance ranked behind each other gquntry in 1970 and 1975 and exceeded only Crechoslovakia and Romania. 6 )

Such comparisons can sometimes be misleading, however, because it is well known that the share of nationgl income invested in housing varies systematically with per capita GDP.I7 The relationship observed for earlier periods, for example, had been that of an inverted-U, with the share of output devoted to housing investment first rising with GDP per capita and then falling beyond a certain level. To gauge Poland's comparative performance, Figure 1 illustrates the "normal" relationship estimated to exist between housing investment and GDP per capita and the observed levels for Poland, the comparator countries of Table 3 , and a number of other countries with similar incomes. To simplify comparison, the "normal" relationship is illustrated only for 1975 (although per capita GDP is expressed in 1981 US\$), and t:a share of hqusing in total output (housing investment to GDP) is showing for 1975.

The figure indicates that Poland's level of investment in housing in 1975 was nearly 1.5 percentage points (about 25 percent) below the "normal" relationship between housing investment and GDP, for its level of GDP per capita. While Czechoslovakia was also beluw the norm in 1975, it had a less serious quantitative housing deficit than Poland in 1975, and hence less pressure to increase investment. of the other socialist countries, Romania had a comparative housing deficit most similar to Poland in the 1970s, and yet was able to devote a substantially higher fraction of national income to housing invastment than was Poland. This is particularly noteworthy given that at

6/ Recall that by 1980 , Czechoslovakia had achieved virtual parity between dwellings and households, thereby lessening effective demand for investmeat.

I/ See, for example, the discussion of the well-known Burns-Grebler relationship between housing investment and per-capita GDP in $S$. Mayo, S. Mal pezzi, and D. Gross (1986).

8/ The "normal" relationship is based on a regression equation relating the share of housing in total output to GDP per capita, population growth rates, and rates of growth of urban population to total population for a sample of 48 countries, following the functional form described in Leland Burns and Leo Grebler (1976). 
FICURE

SHARE OF HOUSING INVESTMENT TO GROSS DOMESTIC PRODUCT

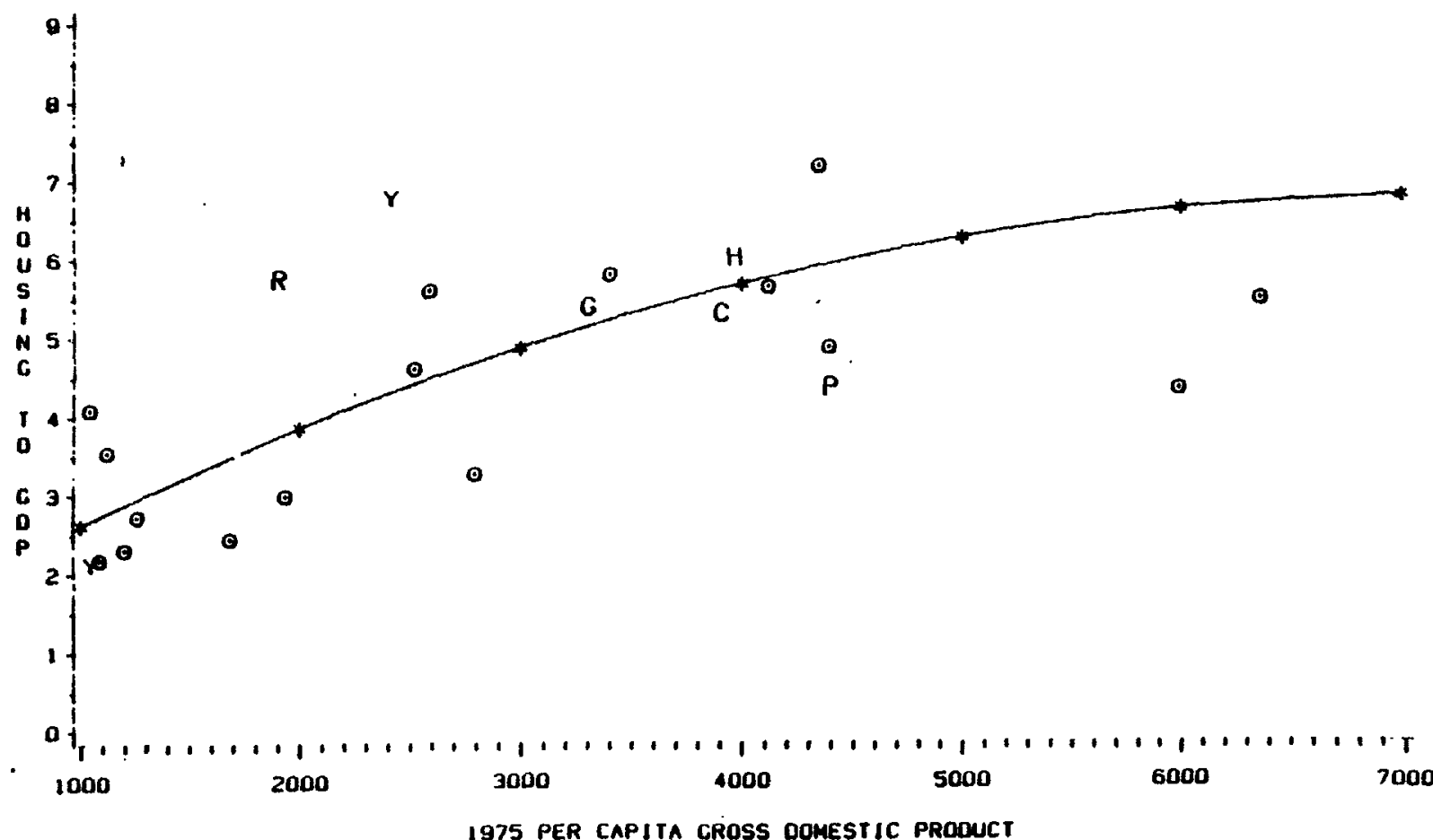

(1981 U.S. DOLLARS)

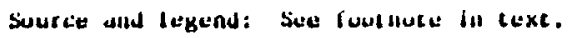

Notes to Figure 1: Data on GDP per capita were based on official exchange rates in 1981. The "normal" relationship portrayed moreover is based on substituting into the estimated equation mean values of population-related variables for Europe and North America, rather than for all countries on which the equation was estimated. Socialist countries in the sample are indicated by the following letters: $\mathbf{C}=$ Czechoslovakia, $\mathrm{H}=$ Hungary, $\mathbf{P}=$ Poland, $\mathbf{R}=$ Romania, and $Y=$ Yugoslavia. Greece, shown for comparison, is indicated by the letter G. 
Romania's lower level of GDP per capita, it is expected that comparatively lower levels of investment would be forthcoming. Yugoslavia's housing investment has, similarly, exceeded considerably the norm for countries with similar income levels. Thus on average Poland appears to have been investing relatively less than both countries with similar income levels and countries that have had similar housing deficits in the recent past.

\section{B. Ig There Labor Market Disequilibrium?}

We argue that labor markets are distorted if there is evidence that (1) internal migration is less than should be expected, and (2) wage rates are distorted. In this section, we examine evidence on Polish internal migration and wage rates relative to those of other countries, and find some support for the existence of labor market disequilibrium. The next section examines the evidence more closely based on econometric models of both migration and wage rates.

Is The Flow of Labor Affected?

Poland's labor market, like that in many centrally-planned economies, has often shown signs of excess demand. The Polish labor force grew more slowly than population in the $1970 \mathrm{~s}$ and 1980s. The World Bank (1987) analysis of the labor market argues that labor turnover rates of around 20 percent in the 1980 s have been relatively low given significant labor shortages, and suggests that the low rate of turnover may be due to housing shortages that limit labor mobility and to modest wage differentiation between most industrial sectors which results in little incentive to change jobs.

Limited labor mobility in Poland has not been the result of explicit policies limiting migration. Administrative controls on migration to large cities were put into effect in 1954 and rescinded as late as 1984 in Warsaw, but analysts argue the controls were unenforceable and ineffective in stemming migration (Ciechocinska, 1987). A policy of both active and passive decentralization of industrial establishments from large cities to towns and rural areas, attempted during the mid-1950s until 1970, was also ineffective, as many workers declined to move to their establishments' new locations because of insufficient housing in the new locations, among other reasons (Ciechocinska, 1987).

Policies labeled "lagged urbanization" (Jedraszko, 1983) or "economizing on urbanization" (Ofer, 1977) have provided the government of Poland with the instruments of an implicit migration policy. Ofer (1977) argues that socialist countries restrict urban investments in order to maximize investment resources allocated to industry. The planners thus restrict the levels of urban infrastructure and services 
per migrant, including investment funds allocated to housing, $\underline{9}$ and use high capital-to-labor ratios in urban industries. Reduced levels of urban investments leads to "migration substitution" (Fallenbuch1, 1977) or commuting from rural residences to urban workplaces, an important and large phenomenon in Poland.

Internal migration in Poland, as in most socialist countries, tends to be lower than in market economies. For example, in 1971 internal migration per 1600 population in Poland was 26.7 , while it was 65.2 in the U.S.A. and 60.9 in West Germany (Fallenbuchl, 1977). Poland's rate of internal migration was similar to that of Hungary and Czechoslovakia but higher than that of East Germany, which was 15.4 per 1000 population in 1971 (Fallenbuch1, 1977).

The rate of total internal migration per 1000 population in Poland has declined steadily since the 1950s. Up until 1973, the rate of rural-rural migration exceeded the rate of rural-urban migration. Rural-rural migration has acted as a form of migration substitution, when housing in urban areas has been unavailable for migrants. Frenkel (1983) estimates that in the period 1960-1970 sixty percent of the movement of labor from farm to non-farm work involved such partial abandonment of farm work. In 1978, about one-half of the rural population was employed in non-agricultural sectors. The cost of commuting to work for this group, however, has been tigh and has hurt labor productivity (Fallenbuch1, 1977; Jedraszko, 1983).

From 1946 to 1985, net (rural-urban) internal migration in Poland totaled almost 6 million people, an annual average of about 150,000 people. These population shifts can be divided into three main periods: two high net-migration periods (1946-1953 and 1970 to the present) and one low net-migration period (1954-1970) (Frenke1, 1983)..

In the first period of high net-migration, 1946-1953, net: migration averaged 174,000 annually. Poland went through 1 and reform and changes in agricultural policy. Land reform created a majority of. small landholders in farming, which at first reduced rural-urban migration. Later in the period, the government forced deliveries of agricultural products and attempted farm collectivisation, stimulating the flow of population out of rural areas.

The period 1954-1970 was one of low net-migration, which averaged 104,000 annually. The pace of industrialization slowed down, and the government began its policy of industrial decentralization. A.s a result of the administrative controls placed on migration to large

9/ We found, for example, a strong statistical correlation of 0.71 between 1980 per capita housing investment and 1985 net migration per 1000 population. 
cities which began in this period, there was an increase in commuting from rural homes.

In the period since 1970 , net migration has averaged 176,000 annually, although since 1980 it has declined to 146,000 people, due to the slowdown in the economy and lower investment levels in boch industry and housing. During the 1970 s, rapid growth in non-agricultural investments and output spurred rural-urban migration, as did agricultural modernization, increased mobility of older farmers who handed over their land in return for pensions, the entry of Poland's baby-boom generation into the labor force, and the acceleration of housing investments.

To sum up, throughout the post-war period in Poland, a whole range of policies--industrial, agricultural, and urban--have had both direct and indirect effects on migration rates. In section $V$, we present the results of our model component of migration as a function of demographic variables, wages, and the housing shortage.

\section{Are Wage Rates Distorted?}

The World Bank (1987) analysis of the Polish labor market finds that "in spite of goods shortages the household sector is more responsive to real wages than are firms", providing evidence that labor responds to wage variations.

The level of wage dispersion across aggregate economic sectors in Poland is high when compared to Western market economies and even when compared to other East European countries; by 1976, the latest year available for comparison, Poland had the most unequal earnings structure among its East European neighbors (Askansas and Levcik, 1983). A significant factor in this dispersion is the favored position of mining in the wage structure; the mining wage is almost twice that of the average manufacturing wage. Within the manufacturing sector, Poland's wage dispersion is lower than in Western market economies but still higher than in other. East European countries, as indicated in Table 4.

Regional-level (voivodship) data on average monthly wages for 1985 in all sectors and in the industrial sectors is presented in Table 5. The coefficient of variation indicates that average regional industrial wages were more variable across voivodships than were average regional all-sector wages.

Our analysis of the relationship between wage rates and the housing shortage, presented in the next section, uses a model of wages as a function of a region's industrial mix and housing shortage. We found a strong and robust relationship between these factors.

\section{EMPIRICAL MODELS}

In this section we test three behavioral models, designed to answer the following questions: 
1. Does housing investment respond to housing market disequilibrium?

If no, the presumption is that adjustment to labor market disequilibrium is more likely to occur through impacts on migration flows and thence on wage structures.

2. Is migration influenced by housing shortages?

If no, then one may conclude that wage differentials are sufficient to have offset the reluctance to migrate. If yes, there may be assumed to be costs to both industry and individuals of reduced mobility, costs which industry will attempt to offset by offering higher wages, to induce. workers to migrate despite housing shortages. 10 /

3. Are wages influenced by housing shortages?

If yes, then one may conclude that relative to the situation in market economies wages are distorted--too high in some regions and industries and too low in others, with the result that productivity and output suffer.

Table 4: STANDARD DEVIATION RELATIVE TO AVERAGE

BARNINGS IN THB MAIN AND INDUSTRIAL

SECTORS IN SELECTED RAST EUROPEAN COUNTRIES, 1976

\begin{tabular}{lcc}
\hline & $\begin{array}{c}\text { Main } \\
\text { Sectors }\end{array}$ & $\begin{array}{c}\text { Industrial } \\
\text { Sectors }\end{array}$ \\
\hline Poland & 15.1 & 19.5 \\
Bulgaria & 12.5 & 15.7 \\
Czechoslovakia & 13.4 & 15.2 \\
Hungary & 7.7 & 15.0 \\
Romania & 9.1 & 12.7 \\
USSR & 18.8 & 17.3 \\
\hline
\end{tabular}

Source: Table 10.3, Askansas and Levcik (1983).

Industries may respond in one of two ways-either by offering higher money wages or by offering higher non-wage benefits, particularly company housing. This latter possibility seems to have been increasingly common in recent years, though the data were 
Table 5. Aver age Honthly Hages in Poland, 1985.

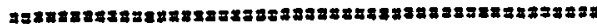
1985 Average Monthly

Hages (alobys)

Vol rodships

Total

Industrial

\begin{tabular}{|c|c|c|}
\hline POLANo & 20,005 & 22,566 \\
\hline Harsau City & 20,477 & 21,318 \\
\hline Biala Podlasta & 17,055 & 17,187 \\
\hline Bialystok & 17,611 & 18,311 \\
\hline Bielsko-Biala & 18,837 & 19,177 \\
\hline Bydogoszcz & 18,209 & 18,611 \\
\hline Chele & 17,135 & 17,030 \\
\hline Ciechanou & 17,135 & 17,263 \\
\hline Czestochoua & 19,101 & 20,114 \\
\hline Elblag & 18,783 & 19,518 \\
\hline Gdanst & 20,018 & 22,438 \\
\hline Gorzov & 18,627 & 18,932 \\
\hline Jelenia Gora & 18,816 & 20,384 \\
\hline Xalisz & 17,668 & 18,206 \\
\hline Katovice & 27,450 & 33,258 \\
\hline Kielee & 17,698 & 18,808 \\
\hline Konin & 19,830 & 23,691 \\
\hline Koszalin & 19,238 & 18,655 \\
\hline Krakou City & 19,836 & 22,097 \\
\hline Krosno & 17,260 & 17,853 \\
\hline Legnica & 22,751 & 28,116 \\
\hline Leszno & 18,477 & 18,319 \\
\hline Lublin & 18,390 & 19,401 \\
\hline Lon2a & 16,524 & 17,210 \\
\hline Lodz Cisy & 19,073 & 19,856 \\
\hline Nouy Sacz & 17,115 & 18,723 \\
\hline Olsztyn & 17,791 & 17,772 \\
\hline Opole & 18,778 & 19,473 \\
\hline Ostroleka & 17,101 & 17,967 \\
\hline Pila & 18,100 & 18,514 \\
\hline Piotrkov & 19,477 & 21,537 \\
\hline Plock & 17,916 & 19,251 \\
\hline Poznan & 19,156 & 19,901 \\
\hline Przeorsl & 17,039 & 17,436 \\
\hline Radion. & 18,073 & 18,985 \\
\hline Rzeszow & 17,996 & 19,094 \\
\hline Siedlce & 17,358 & 17,851 \\
\hline Sieradz & 17,451 & 18,202 \\
\hline Skierni tuice & 17,609 & 18,377 \\
\hline Slupsk & 18,240 & 18,821 \\
\hline Suvalki & 17,690 & 17,793 \\
\hline Srczecin & 19,430 & 21,109 \\
\hline Tarnobrzeg & 19,162 & 22,024 \\
\hline Tarnev & 17,963 & 19,144 \\
\hline Torun & 17,937 & 18,409 \\
\hline Halbrzych & 20,560 & 23,057 \\
\hline Hloclavek & 17,609 & 18,149 \\
\hline Uroclay & 19,059 & 19,685 \\
\hline Iamose & 16,995 & 17,413 \\
\hline lielona Gora & 18,387 & 18,787 \\
\hline Inted Average & 20,005 & 22,566 \\
\hline Minieus Value & 16,524 & 17,030 \\
\hline Haxiaus Value & 27,540 & 33,258 \\
\hline Standard Deviation & 1,719 & 2,804 \\
\hline Coeff. of Variation & 97 & 128 \\
\hline
\end{tabular}

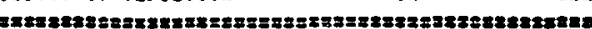


In each of the three components of our model we have used ragression analysis to test the significance of relationships between the housing and labor markets, with the data described in Annex $A$. In each case we have found, upport for the model.

Our empirical model uses the subnational region in Poland called the "voivodship" or district as the geographical unit of analysis. In 1975, the boundaries of the voivodships were altered to create a total of 49 voivodships from what had been 22 voivodships. The large cities in Poland--Warsaw, Lodz, Krakow, and Poznan--with their surrounding towns are also classified as voivodships.

\section{A. Housing Investment and the Housing Shortage}

We have already established, in section III, that housing market disequilibrium exists in Poland. It remains to establish whether housing investment responds to the disequilibrium. The answer requires a model of housing investment as a function of the housing shortage and indicators of housing need. If the housing market behaves "normally", we would expect investment to respond positively to both factors:

$$
\text { Housing Investment }=\underset{(+)}{\mathrm{f} \text { (Housing Shortage, Housing Needs) }}
$$

We examine two types of housing investment in the model: (1) 1981 per-capita housing investment by the socialized sector (HINV) and (2) 1981 per-capita housing investment by the nonsocialized sector (NSHINV). The housing shortage variable is the number of households per 100 dwelling units in 1980 (HHPER). Housing needs are measured by an index of the age distribution of the population, the ratio of births per 1000 to deaths per 1000 population in 1980 (AGEINDEX), and by an index of new housing demand, marriages per 1000 plus divorces per 1000 population in 1980 (NEWHHDEX). Results of equations describing socialized and nonsocialized housing sector investments are presented in Table 6 .

Housing investment does not respond positively to the housing shortage, either in the socialized sector which controls the majority of investments, or in the unplanned nonsocialized sector, which in a socialized economy should behave most like a normal housing market. The demographic variables AGEINDEX and NEWHHDEX are significant in their relation to nonsocialized housing investment but, counter to our expectation, negatively. II These results suggest that "market signals"

11/ The lack of a relationship between housing investment and the housing shortage may be due in part to the separation of investment planning for housing, which is controlled at the voivodship level, and industrial investment planning, controlled at the national level. For a discussion of the problems of physical (settlement) planning vis-a-vis economic planning in Poland, see Andrzej Jedraszko (1983). 


\section{Table 6: RESULTS OP HOUSING INVBSTMENT RRGRESSION}

\begin{tabular}{lcc}
\hline $\begin{array}{l}\text { Independent } \\
\text { Variables }\end{array}$ & $\begin{array}{c}\text { Dependent } \\
\text { HINV }\end{array}$ & $\begin{array}{c}\text { Variable } \\
\text { NSHINV }\end{array}$ \\
\hline CONSTANT & $\begin{array}{c}4.138 \\
(2.946)\end{array}$ & $\begin{array}{c}5558.048 * * \\
(1364.906)\end{array}$ \\
HHPER & -0.01 & -10.938 \\
10.938 & $(0.03)$ & $(13.778)$ \\
& -0.002 & $-3.624 *$ \\
AGEINDEX & $(0.004)$ & $(2.039)$ \\
& -0.001 & $-29.353 * *$ \\
NEWHHDEX & $(0.008)$ & $(3.929)$ \\
& 0.00 & 0.69 \\
Ad justed R2 & & \\
\hline
\end{tabular}

Standard Errors in parentheses * = significant at 0.90 level $* *$ = significant at 0.99 level

concerning housing shortages and incremental demand are not being translated into increased investment. Indeed the fact that the R2 statistic for HINV is equal to zero is a confirmation of the basic observation that housing investment is occurring in a way that is less than rational.

\section{B. Net Migration and Housing Market Disequilibrium}

If housing market disequilibrium affects the labor market through compensatory differentials for higher housing costs that are incorporated into the wage rate, then this not only affects the existing labor pool, but also the ability of establishments to attract labor from other regions. Labor migration is thus an intermediate 1 ink in the relationship between the housing and labor markets. We use several simple models of migration to examine this relationship. In each of the models tested, migration is treated as a function of the wage level in the region and of alternative measures of recent changes in the housing shortage in a region. 
The basic model that we test is one in which we expect that net migration is positively related to the wage level in an area but negatively related to increases in the housing shortage. Three simple models are presented in Table 7. In the first two, net migration per 1000 people in 1985 (MIGPT) is expressed as a function of the 1985 all-sector wage index (WAGEINDEX) and of two measures that are expected to be related to recent changes in housing shortages, dwelling completions per capita in 1980 (DC80) and housing investment per capita in 1981 (HI81). In the case of each of the latter variables, it is expected that the higher its level, other things equal, the greater will have been the reduction in the housing shortage ratio. Problems of data availability prevented using contemporaneous measures of the latter two variables. Based, however, on examination of data for earlier years on both dwelling completions and housing investment, there appears to be a high degree of year-to-year correlation in such data, such that data for 1980 and 1981 are expected to provide reasonable pros: $a$ for more recent periods.

A third model is cast in terms of changes in both wage levels and in the housing shortage ratio. In it, MIGPT is expressed in terms of the difference between 1978 and 1981 housing shortages (HHDIFF), and the difference between 1984 and 1985 average azgregate monthly wages (WACEDIFF). The expectation is that migration is positively related to changes in the wage level and negatively related to the change in housirg shortage.

Table 7 presents the results of our regressions. The dependent variable in each case is net migration per 1000 people in 1985 (MIGPT), positive if there is net in-migration, negative if net outmigration.

In columns (A) and (B) the results of the two models based on the wage level and recent housing investment (or dwelling completions) are shown. Although the models have only moderate explanatory power (R2 $=0.41$ and 0.35 ), both the housing investment and wage level variables have the expected sign and are statistically significant. Higher wage levels and greater levels of investment in housing are associated with higher levels of migration.

Column (C) presents the results of the nodel which is estimated in terms of wage and housing shortage changes. The HHDIFF variable is the 1978 housing shortage subtracted from the 1981 housing shortage; an increase in the variable, therefore, represents an increase in the housing shortage. The model gives basically the same results as the other two models, with a similar degree of explanatory power (R2 = 0.31 ) and indicating that more rapidly changing wage levels are positively associated with migration, but that migration is deterred when housing shortages are increasing more rapidly. 
Table 7: RESULTS PROM NBT MIGRATION REGRESSIONS

\begin{tabular}{|c|c|c|c|}
\hline \multirow{2}{*}{$\begin{array}{c}\text { Independent } \\
\text { Variables }\end{array}$} & \multicolumn{3}{|c|}{ Dependent Variables } \\
\hline & $\begin{array}{c}\text { (A) } \\
\text { MIGPT }\end{array}$ & $\begin{array}{c}\text { (B) } \\
\text { MIGPT }\end{array}$ & $\begin{array}{c}\text { (c) } \\
\text { MIGPT }\end{array}$ \\
\hline CONSTANT & $\begin{array}{l}-9.536 \\
(1.676) * * *\end{array}$ & $\begin{array}{l}-9.578 \\
(1.757) \times * *\end{array}$ & $\begin{array}{l}-7.732 \\
(1.394) * \% \% \%\end{array}$ \\
\hline DC80 & $\begin{array}{l}454.722 \\
(129.550) * * *\end{array}$ & & \\
\hline HINV81 & & $\begin{array}{l}0.025 \\
(0.009) * * * *\end{array}$ & \\
\hline HHDIFF & & & $\begin{array}{l}-0.362 \\
(0.132) * * * *\end{array}$ \\
\hline WAGEINDEX85 & $\begin{array}{l}0.062 \\
(0.019) * * * *\end{array}$ & $\begin{array}{l}0.067 \\
(0.020) * k *\end{array}$ & \\
\hline WAGEDIFF & & & $\begin{array}{l}0.0020 \\
(0.0004) * x *\end{array}$ \\
\hline Ad justed R2 & 0.41 & 0.35 & 0.31 \\
\hline
\end{tabular}

Standard errors in parentheses

* = Significant at $90 \%$ level

* = Significant at $95 \%$ level

*** = Significant at $99 \%$ level

In sum, although our model of migration flows in Poland is a simple one, explaining only a small part of the variation in interregional migration, it suggests that housing shortages influence net migration patterns in a manner consistent with our model: households appear to move in response to wage differentials but are deterred from doing so when housing shortages are great.

\section{c. The Wage Rate and Housing Market Disequilibrium}

The above sections have shown that the housing market has been in persistent disequilibrium, and that the interregional labor supply is depressed by the housing disequilibrium. Are workers then compensated for housing cost differential? The analysis of the most direct 1 ink between the housing and labor markets in our model indicates that they are. Higher average wages do tend to be associated with greater housing shortages. 
We use a modified earnings regression model to examine the relationship between wage rates and housing shortages. An earnings regression associates the wage level with the industrial or occupational mix within a region. We add an indicator of the housing shortage to measure explicitly the relationship between wages and the housing shortage. The model uses three different wage indices: the aggregate wage, the industrial wage, and the construction sector wage. A logarithmic functional form was used so that the coefficient estimate for the housing shortage represents the elusticity of the wage rate with respect to the housing shortage.

Table 8 shows the results of the earnings regressions of the aggregate relative wage (WAGEINDEX), the industrial relative wage (WGINDDEX), and the construction relative wage (WGCONDEX), on the housing shgrtage (HHINDEX) and the appropriate industry mix categories. 127 Four aggregate economic sectors--industry, construction, transportation and communications, and trade-were used to construct the respective employment share variables MIXIND, MIXCON, MIXTRANS, AND MIXTRADE. Eight industrial subsectors-energy and fuel, metallurgy, electrical machinery and electronics, chemicals, minerals, paper and pulp, light industry, and food processing--were used to construct the respective employment $=$ hare variables MIXENERGY, MIXMETAL, MIXELEC, MIXCHEM, MIXMINERAL, MIXPAPER, MIXLIGHT, AND MIXFOOD. 13 I

The regression results are broadly supportive of our hypotheses. In all three of the different equations explaining relative wages the sign of the housing shortage variable is positive. In the case of the equation for the overall average wage the estimated elasticity of relative wages with respect to housing shortages is 0.32 , but insignificant. In the case of the industrial wage index, the estimated elasticity is equal to 0.725 and is highly significant; in the case of the construction wage index, the estimated elasticity is 1.002 ,

12/ In the case of the construction sector wage, subsector industry share data were unavailable by voivodship, so the relative construction wage is regressed only on the housing shortage.

13/ To prevent collinearity problems in the earnings regression for the industrial wage, the food processing industry share was omitted from the regression. 
Tahle 8: RESULTS PROM EARNINGS REGRESSIONS

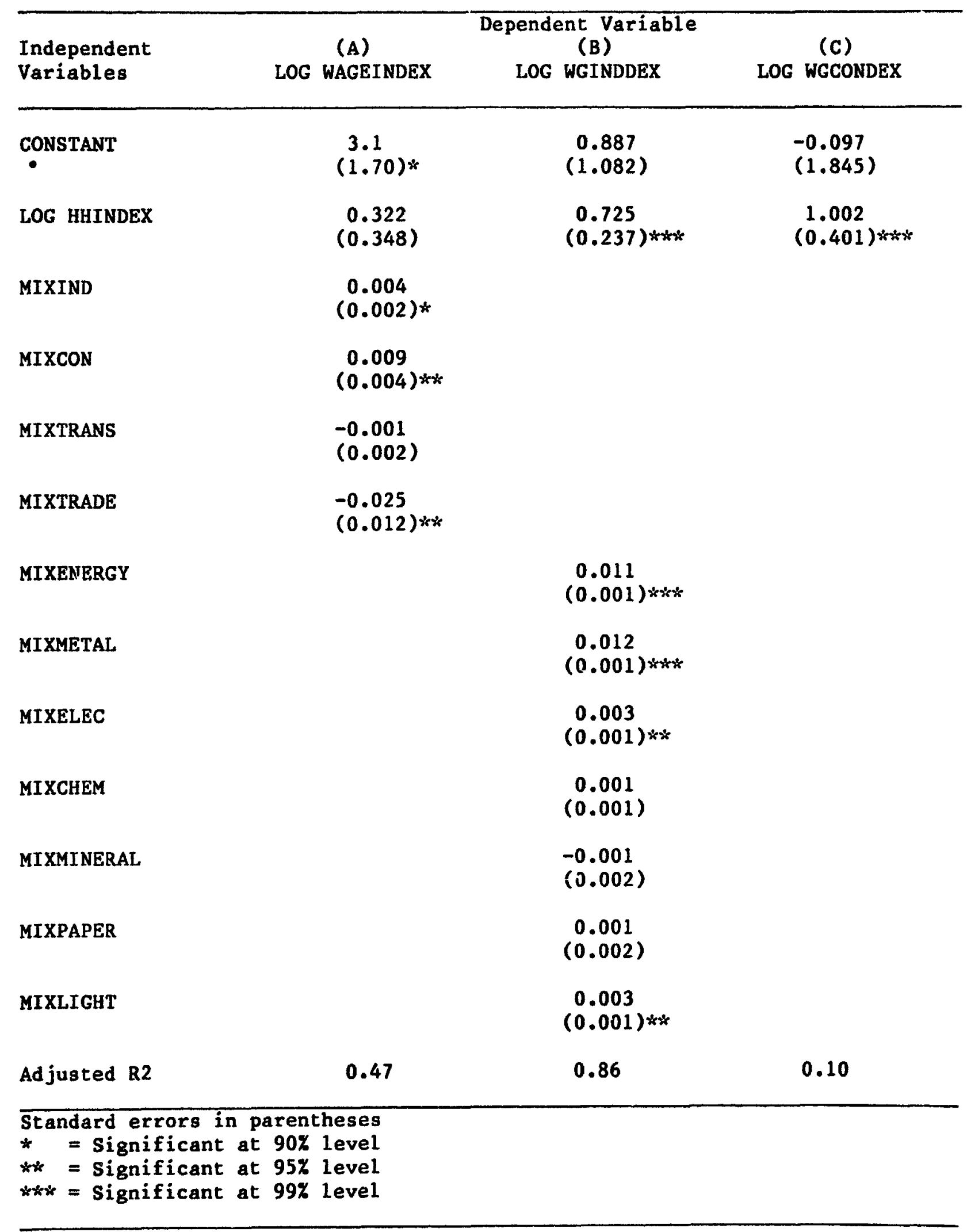


and is also highly significant. $14 /$ Thus in the case of the two specific industrial groupings, a one percent change in the housing shortage ratio is associated with a change in wage levels of from between seven-tenths of one percent to one percent.

These results are lausible in their patterns across industrial groupings in that they follow from two simple and intuitive notions of how the elasticity of wage differentials should be expected to vary depending on the elasticity of demand for labor and the demand for housing. The pattern one finds, for example is one in which the elasticity of wages with respect to housing shortages is lowest for the aggregate, city-wide, wage, and is higher for the two specific industries--"industria:" and construction. The resposiveness of wage rates to housing shortages will depend on two key economic paraneters that affect the supply curve and the demand curve for labor. If housing shortages shift the labor supply curve to a greater degr'e for some occupations or industries than others, then the equilibrium wage rate will shift relatively more in the face of a given labor demand curve. Also, if the demand curve for some occupations or industries is relatively more inelastic than for others, then a given shift in the labor supply curve will tend to produce a greater response in the equilibrium wage in those groups characterized by more inelastic demand.

The relationship between housing demand and the degree to which housing shortages will shift the supply curve for labor is determined by the magnitude of the compensatory wage differential that will be demanded by workers of a given type in response to being required to accept less than cptimal quantities of housing. While this depends ultimately on the parameters of the utility functions of workers of different types, and little empirical research is available that informs us about this issue in Poland, general research indicates clearly that housing is a "normal good", one for which income increases lead to increases in the quantity of the gocd demanded. 15 This appears to be no less 16 gue in centrally planned economies than in market economies. 167 Thus one would expect that workers who would in

14/ We also tried two other housing shortage indicators in the regressions: urban households per 100 urban dwellings and rural households per 100 rural dwellings. Two of the three wage indices (those for the aggregate and the industrial wage) had greater elasticities with respect to the "composite" housing shortage indicator than to the separate urban and rural housing shortage indicators. It is interesting to note, however, that the rural housing shortage index had a stronger relationship to the wage rate than did the city housing shortage index. This indicates that rural areas, where the primary source of housing is private construction, face more severe housing supply constraints than do urban areas.

15/ See, for example, S. Malpezzi and S. Mayo (1986).

16/ See, for example, Daniel (1983). 
equilibrium demand greater quantities of housing would demand greater compensatory wage differentials in the face of quantitative regtrictions on the availability of housing. This suggests in turn that workers in higher wage categories, for whom optimal housing consumption is higher, would demand higher compensatory differentials, and thus that the elasticity of wage rates with respect to housing shortages for such workers would be higher than that for lower-wage workers.

From the first earnings regression presented in Table 8 , it is apparent that the industrial category that is associated with the highest aggregate wage level is that of "construction", followed by "industry" (the coefficients of the industrial share in these two categories are significant and positive). Thus the patterns of coefficients observed (which indicate that construction wages are more responsive than those of industrial wages and that those in turn are more responsive than those of wages in general to housing shortages) are consistent with the relative ranking of wages (and implicitly of the required compensatory differential) by industry.

The other parameter that influences the sensitivity of wage levels to housing shortages is the elasticity of demand for labor. For industries with inelastic demands for labor, a given shift in the labor supply curve will produce a larger change in equilibrium wages than will be the case in industries with elastic demands. In general one would expect that capital-intensive industries such as those represented in the "industrial" category here (such as energy and numerous manufacturing industries) and possibly construction would tend to be characterized by less elastic labor demands than is the case for many of the broad group of industries that comprise the Polish urban economy. Thus the influence of labor demand parameters on the relative responsiveness of wages to housing shortages also appears to be consistent with estimatea patterns across industrial groups.

In evaluating the magnitude of the estimated wage impacts of housing shortages, it is informative to compare the estimated impacts to those associated with shifts in the industrial mix among voivodships. For a shift in the aggregate industry mix to have an equivalent effect on the aggregate wage as eliminating the average housing shortage, a region would need to have 100 percent of its employment in the industrial sector, about three times the national average, or about 50 percent of total employment in construction, more than six times the national average. The same calculation for the industrial wage reveals that a region would need to have about 65 percent of its industrial employment in the highest-wage energy ard fuel sector, about 10 times the national average employment in that sector. The actual range of employment in the energy and fuels sector is from one percent to fiftyone percent, so the housing shortage is estimated to have as much effect on the average industrial wage as if a voivodship moved from the lowest to the highest employment share of the highest-wage sector. 17 /

17/ Exceptions to this are that much state housing is restricted to low-income households, and a form of housing allowance, Social Aid, goes only to low-income households. 
The foregoing results suggest that the influence of housing shortages on labor markets in Poland is quite large, with depressing effects on place-to-place mobility and a resulting tendency on the part of certain industries to offer compensatory wage differentials in order to offset the high costs and disutility imposed by those shortages. The effect of these disruptions in the Polish labor market is almost certainly to diminish overall productivity and aggregate incomes. For example, even though labor and factor markets in the Polish economy are undoubtedly far from competitive, and hence it is not likely that relative wage levels perfectly mirror relative differences in the marginal productivity of labor, it is nevertheless likely to be the case that, in general, high wages will be found in places with higher than average marginal productivity. Hence, if there is evidence that labor is inhibited from moving to those areas because of housing shortages or other reasons, it is 1 ikely that significant economic costs in terms of foregone productivity will be incurred. While calculating the magnitude of such costs is beyond the scope of this paper, there is little doubt that do exist, and that they represent only one of several sorts of economy-wide economic costs that are incurred as a result of inappropriate housing policy.

\section{CONCLUSIONS AND POLICY IMPLICATIONS}

The evidence is strong that housing policies in Poland have major deleterious consequences for macroeconomic performance. Among the consequences are foregoing high return investments, depressing savings incentives, and distorting labor markets and migration in ways that cause wage differentials to be higher than they would be under competitive conditions. While general equilibrium analysis would be required to establish precisely the economic costs of these distortions, it is clear that they are collectively large and represent a serious penalty for a misguided housing policy. While short-run economic policy in Poland should undoubtedly focus on dealing with external economic relations, a longer-term strategy for Poland's economic recovery should include major reforms in policies affecting the housing sector. Among these reforms are an increase in resource allocation to the housing sector, an expanded role for the private housing sector, restructured housing subsidies, and an increased supply of building materials. Benefits should be felt in an increased return on aggregate investment, lowered housing prices, greater domestic resource mobilization, improved operation of labor markets, and more appropriate wage structures.

\section{A. Increase Resource Allocation to the Housing Sector}

A compelling argument can be made that investment in the housing sector is too low based on observed housing deficits, current investment levels relative to historical trends, investment levels relative to those of other countries at similar levels or with similar housing deficits in the recent past, high market prices in relation to 
production costs, and the unfavorable macroeconomic consequences of such underinvestment.

Increasing infrastructure investment must be seen as an integral part of increasing resource allocation to the housing sector. Housing cooperative officials, municipal officials, and building construction firms all indicate that underinvestment in infrastructure results in less housing throughput. Also, as in the case of housing, comparisons of market prices of urbanized land to land sezvicing costs suggest high incremental rates of return to investments in technical infrastructure for residential development.

\section{B. Expand the Role of the Private Housing Sector}

The private housing sector could play a significantly greater role in housing supply. The number of private dwellings under construction (about 300,000 ) is higher now than ever before, but the annual completion rate is only about 50,000 per year. The average gestation period of six years is highly unfavorable compared to the corresponding period for publicly provided housing, about 17 months. Reasons for this unfavorable showing by the private sector involve limitations on private credit, shortages of building materials, and prohibitions against ownership of more than one dwelling. At present, private housing is predominantly a rural phenomenon. In urban areas, construction of single family houses by the private sector (virtually the only type of housing that people are allowed to build) is constrained by the lack of urban infrastructure and appropriately zoned land.

Realizing the full potential of the private sector will require broad and fundamental reforms, although some lesser steps could significantly improve annual output. Among the changes that should be considered are: (1) making more credit available for private builders at a market rate of interest, (2) ensuring adequate building supplies and establishing mechanisms whereby the private sector could bid resources away from the socialized sector, (3) encouraging development of small enterpreneurs in the building trades and production of building materials, (4) reducing transfer taxes on the private sale of dwellings, (5) encouraging innovation in building materials to permit unit construction costs to fall, (6) providing adequate infrastructure to privately owned land to encourage development, and (7) removing prohibitions against ownership of more than one dwelling. This latter step, in particular, could be expected to lead to expansion of capital for the sector out of private resources.

While the steps just 1 isted would be expected to increase private entrepreneurial incentives to produce housing, several changes in policy with respect to the socialized sector would further increase private incentives. These include: (1) reducing the level of cooperative and possibly state housing subsidies, (2) encouraging greater reliance on owner--rather than tenant-type--cooperatives, and (3) selling off some state housing to tenants, as has recently been done 
in Hungary. Reducing subsidies would not only reduce inflationary pressures, but would make private housing relatively more competitive with cooperative and state housing. The latter two changes would create more saleable stock of housing, particularly in urban areas, and would begin to open up the market for housing. Selling units to tenants would have the added advantages of reducing future subsidies and also creating a source of funds that could be used to provide financing for additional housing.

\section{Restructure and Reduce Housing Subsidies}

There are four main problems with the housing subsidy system in Poland. First, housing subsidies are not "transparent" and thus are difficult to control and to target. A large share of subsidies are implicit, off-budget transfers, or represent contingent claims on government resources. Subsidized interest, especially for cooperative housing, and tax exemptions for enterprises that provide housing for workers are the most prominent examples of large off-budget subsidies. Second, subsidies distort prices, creating disincentives for production of private housing, creating artificial shortages, and raising the market price of housing that becomes available. Because of the generosity of existing housing subsidies, many households would prefer to wait for long periods for housing in the socialized sector rather than to enter the private market, which, in any case, is typified by prices that are not affordable to most households. Third, subsidies reduce incentives to save. Since savings (required down-payments) are only a modest part of housing costs, and since by making greater savings efforts households cannot accelerate the date at which they are able to purchase subsidized housing, households are not inclined to make greater savings efforts than those minimally required for cooperative housing. The aggregate effect of such depressed savings incentives may be quite large, since in most moderately developed countries the principal motivation for household savings is in fact to purchase housing. Fourth, housing subsidies in Poland have a number of inequitable features. They are, for example, largely unrelated to income 18. Thus some high-income families receive large subsidies and many low-income families not only receive no subsidies but actually pay, through an inflation tax, for the housing of better off members of society.

The government is not unaware of some of the problems of the existing housing subsidy system, and has indeed begun a cautious reform of a number of subsidy system features. Reforms are addressed both to reducing subsidies and to restructuring them, although in each area far more thorough changes appear to be necessary. While these reforms are certainly in the right direction, they barely scratch the surface of serious reform. For example, they leave untouched the off-burget interest subsidies for cooperative housing, which, as discussed above, are not only almost as large as budgetary subsidies but also have highly undesirable fiscal consequences. Changing the amortization period without changing other terms of housing loans is thus an inconsequential reform. 


\section{Increase the Supply of Building Materials}

Any discussion of expanding resources for housing and infrastructure in Poland quickly comes to the issue of building materials shortages. The solution foreseen by the Poles is to expand rather than to reallocate production. In discussion of the forthcoming 5-year plan, it was claimed that allowance had been made for expanding building materials production by up to 90 percent in middle-sized building materials establishments. A September 1986 report on bottlenecks in the industry has apparently considered a wider range of alternatives for dealing with supply constraints, including not only increased production, but also reallocating supply, delaying construction in certain sectors, and increasing imports. All of these alternatives are worthy of consideration. 
$\frac{\text { ANNEX }}{\text { Page } 1 \text { of } 2}$

\section{THE DATA}

The data used in our analysis of housing, labor market, and migration flows is regional-level data from annual statistical yearbooks published by the government's Central statistical office (cso). Although commendably thorough, the published statistics do have omisgions from year tc year. For example, regional data on average wages are available only for 1984 and 1985, and an indicator of regional housing shortage-households per dwelling unit--is available only in 1978, 1980, and 1981. Regional-level data on incomes, housing costs and prices, and households was unavailable.

The subnational region in Poland is called a "voivodship" or district. In 1975, the boundaries of the voivodships were altered to create a total of 49 voivodships from what had been 22 voivodships. The large cities in Poland--Warsaw, Lodz, Krakow, and Poznan--with their surrounding towns are also classified as voivodships.

Six types of data were used for the statistical analysis:

1. An indicator of the housing shortage: households per 100 occupied dwelling units.

2. Socialized and private-sector per-capita investments in housing.

3. Demographic variables--births, deaths, marriages, and divorces per 1000 population--as indicators of housing needs. The ratio of births per 1000 population by deaths per 1000 population is used as a rough indicator of the age composition of each voivodship's population. Marriages per 1000 population plus divorces per 1000 population is used as a rough indicator of new household formation. Divorces were added to marriages because some divorces would create additional needs for housing.

4. Net migration--positive if net in-migration, negative if net out-migration--as the migration variable. Total inmigration and out-migration figures by voivodship were unavailable.

5. Average monthly wages in the socialized sector for all sectors, for the industrial sectors only, and for the construction sectors only. 
ANNEX

Page 2 of 2

6. Annual employment for the total socialized economy, for four aggregate subsectors (industry, construction, transportation and communications, and trade), and eight industrial subsectors (energy and fuel, metallurgy, electrical and other machinery, chemicals, minerals, pulp and paper, light industry, and food processing). Data on private-sector employment at the voivodship level was unavailable. Nationally, private employment was about 30 percent of total employment in 1986. Earnings in the private non-farm sector are as much as twice their level in the socialized sector.

Relative measures of the wage, the housing shortage, and demographic variables were constructed as percentages of the national average values for those variables. Employment shares in the four aggregate subsectors (industry, construction, transportation and communications, and trade) and the eight industrial subsectors were constructed as percentage shares in total employment and in total industrial employment respectively. 


\section{REPERENCES}

Askansas, B. and F. Levcik. The Dispersion of Wages in the CMEA Countries (including a comparison with Austria), Reprint-Series Number 70. Vienna, Austria: The Vienna Institute for Comparative Economic Studies, December 1983.

Burns, Leland and Leo Grebler. "Resource Allocation to Housing Investment: A Comparative International Study." Economic Development and Cultural Change, 25 (1), October 1976, pp. 95-121.

Ciechocinska, Maria. "Government Interventions to Balance Housing Supply and Urban Population Growth: The Case of Warsaw." International Journal of Urban and Regional Research, 11 (1), March 1987, pp. 9-26.

Daniel, Zsuzsa. "Public Hosing, Personal Income, and Central Redistribution in Hungary." Acta Oeconomica, $31(1-2), 1983$, pp. 87-104.

Fallenbuch1, Zbigniew M. "National Income Statistics for Poland, 19701980." World Bank Staff Working Paper, no. 776. Washington, D.C.: World Bank, 1985.

"Internal Migration and Economic Development under Socialism: The Case of Poland." In Internal Migration: A Comparative Perspective. Ed. Alan A. Brown and Egon Neuberger. New York: Academic Press, 1977.

Frenkel, I. "Socio-Economic Development and Rural-Urban Migration in Poland." In State Policies and Internal Migration: Studies in Market and Planned Economies. Ed. A.S. Oberai. London: Croom He1m, 1983.

Havlik, Peter and Friedrich Levcik. "The Gross Domestic Product of Czechoslovakia." World Bank Staff Working Paper, no. 772. Washington, D.C.: World Bank, 1985.

Hewett, Edward. "The Gross National Product of Hungary: Important Issues for Comparative Research." World Bank Staff Working Paper, no. 775. Washington, D.C.: World Bank, 1985.

Jackson, Marvin. "National Accounts and the Estimation of Gross Domestic Product and Its Growth Rates for Romania." World Bank Staff Working Paper, no. 774. Washington, D.C.: World Bank, 1985.

Jedraszko, Andrzej. "Physical Planning in Poland: The Changing Fate of the Doctrine." In Dilemmas in Regional Policy. Ed. A. Kukl inski and J. Lambooy. Berlin: Mouton Publishers, 1983, pp. 435-457. 
Malpezzi, Stephen and stephen $K$. Mayo. "The Demand for Housing in Developing Countries." World Bank Staff Working Paper, no. 733. Washington, D.C.: World Bank, 1986.

Mayo, Stephen K. "Annex VI (Housing, Health, and Education and Training)." In Poland: Reform, Adjustment, and Growth. Washington, D.C.: World Bank, April 13, 1987.

, Stephen Malpezzi and David Gross. "Shelter Strategies for the Urban Poor in Developing Countries." In World Bank Research Observer, Washington, D.C., July 1986, Pp. 183-203.

Ofer, Gur. "Economizing on Urbanization in Socialist Countries: Historical Necessity or Socialist Strategy." In Internal Migration: A Comparative Perspective. Ed. Alan A. Brown and Egon Neuberger. New York: Academic Press, 1977.

United Nations Economic Commission for Europe (E.C.E). Human Settlements situation in the ECE Region around 1980. New York: United Nations, 1986.

World Bank. "Annex I (The Economic System)." In Poland: Reform, Adjustment, and Growth. Washington, D.C.: World Bank, April 13, 1987. 